Соболсва-Терещенко О.А., Жарнікова В.В.

\title{
ОСОБЛИВОСТІ БУХГАЛТЕРСЬКОГО ОБЛІКУ РОЗРАХУНКІВ 3 ПОКУПЦЯМИ В УМОВАХ ЗАСТОСУВАННЯ ПРОГРАМ ЛОЯЛЬНОСТІ
}

\begin{abstract}
У статті викладені результати дослідження особливостей відображення у бухгалтерському обліку розрахунків з покупцями в торгівлі при застосуванні програм лояльності. Авторами представлено загальну класифікацію програм лояльності, виходячи з потреб їх правильної оцінки в обліку, узагальнено $i$ згруповано зміст і можливі варіанти застосування сучасних інструментів програм лояльності 6 залежності від бази їх нарахування, способу вираження та форми надання. В статті розглянуто $i$ систематизовано переваги і недоліки дисконтних програм, програм бонусів і програм винагород, які можуть виникнути в результаті застосування дисконтів, поворотних знижок (ребейтів), відшкодувань, бонусів або інших видів винагород. В результаті досліджень авторами узагальнено особливості обліку програм лояльності, запропоновано до використання спеціальні рахунки з обліку їх доходів $і$ витрат в торгівлі, а також викладені перспективи подальших досліджень 3 даної проблематики з огляду впровадження МСБО.
\end{abstract}

Ключові слова: бухгалтерський облік, розрахунки з покупчями, програми лояльності, МСБО, торгівля, дисконтні програми, бонусні програми, програми винагороди.

Постановка проблеми. За динамічних умов сьогодення, пов'язаних з інтеграцією України в європейське господарське товариство, зростанням конкуренції у ринковій економіці, стрімким розвитком інформаційних технологій 3'явилася термінова необхідність впровадження нових ефективних інструментів управління продажами товарів 3 метою максимізації прибутку в сфері торгівлі.

Попит на спеціальні пропозиції 3 боку покупців та клієнтів продовжує зростати 3 кожним днем. Таким чином, все більше роздрібних та оптових компаній 3 продажу товарів освоюють новий перспективний напрямок заохочень покупців в торгівельної діяльності - програми лояльності.

Необхідність розроблення рекомендацій щодо обліку операцій по розрахунках 3 покупцями 3 наданням знижок, бонусів та кеш-беків, коректності відображення таких операцій у фінансовій звітності компаній, правильності визначення оптимального рівня інструментів заохочення покупців в рамках впровадження та ведення ефективних програм лояльності зумовлює актуальність дослідження.

(C) Соболсва-Терещенко Олена Анатоліївна, к.е.н., старший викладач кафедри управління Факультету інформаційних технологій та управління Київського університету імені Бориса Грінченка, тел: +380677901161, e-mail: o.tereshchenko@kubg.edu.ua

Жарнікова Валерія Владиславівна, аспірант кафедри обліку та оподаткування Факультету обліку, аудиту та інформаційних систем Київського національного торговельно-економічного університету, тел: +380934162396, e-mail: v.zharnikova@gmail.com
Аналіз останніх досліджень і публікацій. До проблематики розкриття суті та класифікації програм лояльності зверталося багато науковців та вчених-економістів, зокрема: Т. Валентинова [1], М.I. Ларка, М.В Мірошник, В.А. Анохін, І.С Олійник [2], І. В. Юрко, О. М. Карась [3], М.М. Іваннікова [4], Д. А. Козейчук [5], 3. В. Кулікова [6], І. П. Широченська [7].

Праці названих вчених стали основою подальшого, докладнішого дослідження програм лояльності, визначення проблем їх правильної оцінки та класифікації для потреб ефективного управління продажами.

Також окремі аспекти функціонування програм лояльності знайшли своє відображення в працях зарубіжних вчених та практиків: С. Бутчера [8], П. Гембла [9], Ф. Ньюэлла [10], Ф.Райхельда [11].

Однак не всі аспекти цієї фундаментальної проблеми достатньо опрацьовано 3 огляду на іï багатогранність та наукову дискусійність питання доцільності застосування тих чи інших програм лояльності з метою розширення обсягів і масштабів збутової та торгівельної діяльності, збільшення прибутків від продажів, формування позитивного іміджу компаній.

Таким чином, незважаючи на певну кількість наукових публікацій вітчизняних та закордонних науковців з цієї проблематики, існує об'єктивна потреба у комплексному обгрунтуванні питань, пов'язаних $з$ класифікацією та оцінкою наданих знижок, нарахованих та списаних бонусів та повернення кеш-беків 3 точки зору обліку операцій по розрахунках з покупцями в умовах застосування програм лояльності.

Формулювання цілей наукової статті. Актуальними науково-прикладними цілями 
статті $є$ дослідження та узагальнення основних підходів до сутності програм лояльності в роздрібній та оптовій торгівлі; висвітлення авторських підходів до класифікації програм лояльності 3 огляду потреб бухгалтерського обліку, розкриття сутності, визначення переваг та недоліків процесу застосування інструментів програм лояльності в торгівлі, узагальнення основних підходів до оцінки програм лояльності у системі бухгалтерського обліку 3 метою визначення перспективних напрямів їх розвитку.

Опис основного матеріалу дослідження. Класифікація програм лояльності в торгівлі необхідна для адекватного розуміння їхньої суті та відповідно для коректного відображення в обліку всіх операцій 3 продажу товарів i розрахунків 3 покупцями із застосуванням інструментів програм лояльності. Економічна суть таких операцій перш за все залежать від економічної природи відносин 3 покупцями та юридичного статусу учасників програм лояльності. Саме це визначатиме методологічні підходи до трактування та класифікації програм лояльності для цілей бухгалтерського обліку.

Програми лояльності застосовуються в якості основного ключового елемента систем лояльності компаній, яка являє собою складну організаційну структуру, до якої також належать ще п'ять елементів, а саме: клієнтська база, маркетинг i менеджмент системи лояльності, технологічно-аналітична платформа та показники ефективності системи лояльності [12].

Програми лояльності також часто ототожнюють 3 всією системою лояльності, хоча сама по собі система лояльності компанії може мати декілька програм лояльності, поєднуючи або розділяючи їх для різних сегментів клієнтів. Також поняття «програма лояльності» іноді плутається 3 поняттям «процесінг системи лояльності», хоча сутність цих понять суттєво відрізняється i процесінг являє собою технологічно-аналітичну платформу 3 комплексної автоматизації ключових компонентів програми, включаючи процесінг з нарахування знижок, балів, бонусів, платформу клієнтської аналітики, системи комунікації з клієнтами, захисту даних і т.д. [12].

Таким чином, поняття «програма лояльності» відрізняється від поняття «система лояльності» та «процесінг системи лояльності». В першому випадку «програма лояльності» входить до складу «системи лояльності» та виступає одним 3 ii основних елементів, а в другому випадку «програма лояльності» $\epsilon$ алгоритмом застосування різних заохочень та привілеїв для покупців та клієнтів, який реалізується через комплексну автоматизацію завдяки «процесінгу системи лояльності».
Для цілей більш глибокого розуміння економічної сутності програм лояльності в торгівлі та 3 метою побудови ефективної моделі бухгалтерського обліку операцій 3 продажу товарів та розрахунків $з$ покупцями із наданням лояльних пропозицій та заохочень необхідно дослідити класифікацію зазначених програм лояльності.

С. Бутчер в залежності від типу входження ділить всі програми лояльності на дві групи: закриті, що передбачають певні обмеження щодо вступу до них, та відкриті програми лояльності, що подібних умов не містять. В залежності від характеру цільових груп i спрямованості С. Бутчер, розрізняє програми лояльності, розраховані на підприємців дистриб'юторів і кінцевих споживачів [8].

Дослідники цієї проблематики Кляченко I.O. та Зозульов О. класифікують програми лояльності споживачів до бренду в залежності від способу надання послуги, типу ідентифікації клієнта в ній, від об'єкту, від способу використовує свго інструментарію, від часу та цілей програми лояльності, від наявності або відсутності вступних бар'єрів та умов для учасників програми. [13].

В своїх дослідженнях програм лояльності Герія І.А виділяє наступні класифікації програм лояльності та відповідні їм типи в залежності: від кількості учасників, від бар'єрів для вступу в програму або від умов для учасників програм, від ступеня прихильності заохочення до факту здійснення покупки, від типу вигоди, яку отримує споживач.[14].

Колектив авторів під керівництвом Ровенського Ю.А., Наточеєвої Н.Н. класифікують програми лояльності за наступними класифікаційними ознаками: цільова аудиторія, ступінь охоплення цільової аудиторії, склад учасників та тип винагород.[15].

Аналіз фахової літератури показав, що найбільш уживаний підхід до класифікації програм лояльності полягає в розподілі їх на чотири частини, причому критерії розподілу в різних дослідників не збігаються. Найчастіше знижки диференціюють за типом винагород або цільовою аудиторією.

На жаль, жодна 3 наведених вище класифікацій не задовольняє вимог щодо розмежування програм лояльності в сфері торгівлі та не може бути покладена в основу системи обліку заохочень та винагород покупців за збільшення обсягів придбання товарів та прискорення розрахунків за цей товар.

За результатами проведеного дослідження видається найбільш доцільним для цілей бухгалтерського обліку в торгівлі керуватися 
класифікацією

програм

спеціалістами

лояльності, компанії PricewaterhouseCoopers (РwC). Виходячи 3 досвіду роботи спеціалістів компанії так званої «великої четвірки», виділяється три види програм надання знижок та бонусів: дисконтні програми, у рамках яких покупці отримують знижку безпосередньо під час купівлі товару; програми відшкодування, у рамках яких клієнтам нараховують певні фінансові вигоди, що надаються згодом у грошовій формі; програми бонусів, у рамках яких клієнти за здійснені покупки отримують бонуси, що можуть бути використані для отримання інших товарів безкоштовно або зі знижкою [16].
Зазначимо, що запропонована спеціалістами PwC класифікація в жодному разі не $\epsilon$ вичерпною для класифікації програм лояльності в торгівлі, проте є найбільш вдалою та враховує всі аспекти розрахунків 3 покупцями в торгівлі 3 наданням знижок, бонусів та кеш-беків операцій, а також дозволяє розрізняти їх 3 точки зору суттєвості безпосередньо для цілей бухгалтерського обліку.

Також для цілей обліку важливо розуміння бази нарахування, вираження та форми надання заохочень та винагород по програмах лояльності, отже наявні на сучасному етапи програми лояльності можна класифікувати за декількома ознаками, характеристику яких наведено в табл. 1.

Таблиця 1

Класифікація програм лояльності в торгівлі для цілей обліку

\begin{tabular}{|c|c|c|c|c|}
\hline № & За часом надання & $\begin{array}{l}\text { За базою } \\
\text { нарахування }\end{array}$ & $\begin{array}{l}\text { За способом } \\
\text { вираження }\end{array}$ & $\begin{array}{l}\text { За формою } \\
\text { надання }\end{array}$ \\
\hline \multirow[t]{10}{*}{1} & \multirow{10}{*}{$\begin{array}{l}\text { Бонусні програми } \\
\text { (програми лояльності, у рамках } \\
\text { яких покупці за здійснені } \\
\text { покупки } \\
\text { отримують заохочення, } \\
\text { що можуть бути використані для } \\
\text { отримання вигод в майбутньому) }\end{array}$} & \multirow{2}{*}{$\begin{array}{l}\text { За оборотом в } \\
\text { грошовому } \\
\text { еквіваленті }\end{array}$} & Бали & $\begin{array}{l}\text { Зарахування в бонусів } \\
\text { ціну майбутніх покупок }\end{array}$ \\
\hline & & & Бонуси & $\begin{array}{l}\text { Обмін бонусів на } \\
\text { довільний асортимент }\end{array}$ \\
\hline & & \multirow{4}{*}{$\begin{array}{l}\text { За обсягом продажу } \\
\text { в натуральних } \\
\text { одиницях }\end{array}$} & Фішки & \multirow{3}{*}{$\begin{array}{l}\text { Обмін бонусів на } \\
\text { визначений перелік } \\
\text { товарів } 3 \text { каталогу }\end{array}$} \\
\hline & & & Ваучери & \\
\hline & & & $\begin{array}{l}\text { Подарункові } \\
\text { картки } \\
\end{array}$ & \\
\hline & & & Пункти & \multirow{5}{*}{$\begin{array}{l}\text { Надання } \\
\text { товарів по пільговим } \\
\text { цінам за умови } \\
\text { накопичення певної } \\
\text { кількості бонусів } \\
\end{array}$} \\
\hline & & \multirow{4}{*}{$\begin{array}{l}\text { За партнерськими } \\
\text { програмами }\end{array}$} & Поінти & \\
\hline & & & Кредити & \\
\hline & & & Умовна валюта & \\
\hline & & & Очки & \\
\hline \multirow[t]{4}{*}{2} & \multirow[t]{4}{*}{$\begin{array}{l}\text { Дисконтні програми } \\
\text { (програми лояльності, у рамках } \\
\text { яких покупці отримують знижку } \\
\text { безпосередньо під час купівлі } \\
\text { товару) }\end{array}$} & $\begin{array}{l}\text { За значної } \\
\text { одномоментної } \\
\text { покупки }\end{array}$ & $\begin{array}{l}\text { Різний відсоток } \\
\text { зниження ціни на } \\
\text { першу, другу чи третю } \\
\text { одиницю } \\
\text { Миттєвий подарунок } \\
\text { до певного товару } \\
\end{array}$ & $\begin{array}{l}\text { Знижка як зменшення } \\
\text { ціни на товар, що } \\
\text { купується }\end{array}$ \\
\hline & & \multirow[t]{3}{*}{$\begin{array}{l}\text { За партнерськими } \\
\text { програмами }\end{array}$} & $\begin{array}{l}\text { Знижка в грошовому } \\
\text { еквіваленті за кожні } \\
\text { витрачені 10, 100, } \\
1000 \text { грн. }\end{array}$ & $\begin{array}{l}\text { Умовно безкоштовне } \\
\text { роздавання товарів } 3 \\
\text { метою реклами }\end{array}$ \\
\hline & & & $\begin{array}{l}\text { Загальний відсоток } \\
\text { зниження ціни на всю } \\
\text { суму замовлення }\end{array}$ & \multirow[t]{2}{*}{$\begin{array}{l}\text { Пропозиції назвати свою } \\
\text { ціну товару }\end{array}$} \\
\hline & & & Купони на знижку & \\
\hline \multirow[t]{5}{*}{3} & \multirow{5}{*}{$\begin{array}{l}\text { Програми винагород } \\
\text { (програми лояльності, у рамках } \\
\text { яких покупці згодом отримують } \\
\text { фінансові вигоди за операції } \\
\text { проведені в минулому) }\end{array}$} & \multirow[t]{2}{*}{ За вчасну оплату } & $\begin{array}{l}\text { Часткове повернення } \\
\text { грошей cash back }\end{array}$ & $\begin{array}{l}\text { Знижка у формі } \\
\text { часткового повернення } \\
\text { коштів }\end{array}$ \\
\hline & & & $\begin{array}{l}\text { Безоплатно наданий } \\
\text { товар }\end{array}$ & Знижка як грошова премія \\
\hline & & $\begin{array}{l}\text { За оборотом в } \\
\text { грошовому } \\
\text { еквіваленті }\end{array}$ & $\begin{array}{l}\text { Повернення на рахунок } \\
\text { всієї суми раніше } \\
\text { списаної оплати }\end{array}$ & $\begin{array}{l}\text { Знижка у формі } \\
\text { повернення всієї суми } \\
\text { коштів }\end{array}$ \\
\hline & & \multirow{2}{*}{$\begin{array}{l}\text { За обсягом продажу } \\
\text { в натуральних } \\
\text { одиницях }\end{array}$} & \multirow[t]{2}{*}{$\begin{array}{l}\text { Подарункові } \\
\text { картки та сертифікати }\end{array}$} & $\begin{array}{l}\text { Знижка як безкоштовне } \\
\text { постачання товарів }\end{array}$ \\
\hline & & & & $\begin{array}{l}\text { Післяпродажна знижка як } \\
\text { коригування ціни }\end{array}$ \\
\hline
\end{tabular}

\footnotetext{
* Розроблено авторами
} 
Отже, якщо в рамках дисконтних програм лояльності знижки надаються покупцеві безпосередньо в момент продажу, то в рамках застосування бонусних програм лояльності та програм відшкодування бонуси надаються продавцем згодом та за умови досягнення покупцем або певного обсягу закупок, або при оплаті товарів протягом обумовленого часу, або при настанні певних умов.
На підставі проведеного дослідження наукових джерел, нормативно-правових документів та спеціальної літератури 3 програм лояльності визначено та охарактеризовано ключові відмінності між програмами лояльності, систематизовано переваги й недоліки операцій 3 продажу товарів із наданням знижок та бонусів, характеристику яких наведено в табл. 2.

Порівняльна характеристика програм лояльності в торгівлі

\begin{tabular}{|c|c|c|c|}
\hline № & $\begin{array}{l}\text { Вид програми } \\
\text { лояльності }\end{array}$ & Переваги & Недоліки \\
\hline 1 & 2 & 3 & 4 \\
\hline \multirow[t]{7}{*}{1} & \multirow{7}{*}{$\begin{array}{l}\text { Бонусні програми } \\
\text { (програми лояльності, у } \\
\text { рамках яких покупці за } \\
\text { здійснені покупки } \\
\text { отримують заохочення, } \\
\text { що можуть бути } \\
\text { використані для } \\
\text { отримання вигод в } \\
\text { майбутньому) }\end{array}$} & $\begin{array}{l}\text { додаткові доходи за рахунок } \\
\text { збільшення частоти покупки; } \\
\text { підвищення суми «середнього чеку»; } \\
\text { зростання чисельності покупців }\end{array}$ & $\begin{array}{l}\text { комерційне використання персональних } \\
\text { даних як утручання в приватне життя } \\
\text { клієнта }\end{array}$ \\
\hline & & $\begin{array}{l}\text { доходи за рахунок продажу карток } \\
\text { членів програми, } \\
\text { членських внесків, платежів партнерів }\end{array}$ & $\begin{array}{l}\text { надання бонусів на наступні покупки } \\
\text { може трактуватися як «хабар» }\end{array}$ \\
\hline & & $\begin{array}{l}\text { вартість обслуговування постійних } \\
\text { клієнтів менша, ніж витрати на } \\
\text { залучення нових }\end{array}$ & $\begin{array}{l}\text { значні капітальні витрати на } \\
\text { установлення й підтримку роботи CRM- } \\
\text { програм }\end{array}$ \\
\hline & & $\begin{array}{l}\text { в основі програми закладені відкладені } \\
\text { платежі, які можуть бути не використані } \\
\text { покупцями }\end{array}$ & $\begin{array}{l}\text { бонусні програми провокують цінові } \\
\text { війни }\end{array}$ \\
\hline & & $\begin{array}{l}\text { у постійних покупців нижча чутливість } \\
\text { до цінових коливань }\end{array}$ & $\begin{array}{l}\text { бонусні програми потребують } \\
\text { комплексної } \\
\text { логістики та обліку }\end{array}$ \\
\hline & & $\begin{array}{l}\text { сильне стимулювання покупців, щоб } \\
\text { отримати бажаний приз, потрібно } \\
\text { набрати пристойну кількість бонусів. }\end{array}$ & $\begin{array}{l}\text { значні поточні витрати матеріальних і } \\
\text { трудових ресурсів, рекламу }\end{array}$ \\
\hline & & емоційне залучення покупців & $\begin{array}{l}\text { винагороди різних систем майже не } \\
\text { відрізняються їх вибір незначний, для } \\
\text { отримання подарунку необхідно витрати } \\
\text { багато, представлені подарунки не є } \\
\text { привабливими для кращих клієнтів. }\end{array}$ \\
\hline \multirow[t]{7}{*}{2} & \multirow[t]{7}{*}{$\begin{array}{l}\text { Дисконтні програми } \\
\text { (програми лояльності, у } \\
\text { рамках яких покупці } \\
\text { отримують знижку } \\
\text { безпосередньо під час } \\
\text { купівлі товару) }\end{array}$} & $\begin{array}{l}\text { додаткові доходи за рахунок } \\
\text { збільшення частоти покупки; } \\
\text { підвищення суми «середнього чеку»; } \\
\text { зростання чисельності покупців }\end{array}$ & $\begin{array}{l}\text { специфіка обліку та порядок визначення } \\
\text { результату від реалізації товарів за } \\
\text { дисконтними програмами не забезпечує } \\
\text { користувачів інформації даними, } \\
\text { необхідними для ефективного аналізу та } \\
\text { управління цих операцій }\end{array}$ \\
\hline & & $\begin{array}{l}\text { низька вартість упровадження програми } \\
\text { лояльності, відсутні дорогі вкладення в } \\
\text { інформаційні системи }\end{array}$ & $\begin{array}{l}\text { проблемність формування прихильності } \\
\text { покупців до окремої групи товарів }\end{array}$ \\
\hline & & прискорення обігу коштів & $\begin{array}{l}\text { пряме скорочення виручки, значна втрата } \\
\text { доходності внаслідок рівняння всіх } \\
\text { покупців }\end{array}$ \\
\hline & & $\begin{array}{l}\text { залучення нових клієнтів за рахунок } \\
\text { передачі неперсоніфікованих карток } \\
\text { покупцями друзям та знайомим }\end{array}$ & $\begin{array}{l}\text { не дозволяє диверсифікувати заохочення } \\
\text { покупців в залежності від їх цінності }\end{array}$ \\
\hline & & $\begin{array}{l}\text { програму легко запустити, в класичному } \\
\text { вигляді вона не вимагає складної } \\
\text { логістики }\end{array}$ & $\begin{array}{l}\text { знижка не втримує споживачів, не робить } \\
\text { їх лояльними }\end{array}$ \\
\hline & & $\begin{array}{l}\text { дисконт - це просто, покупцю не } \\
\text { потрібно пояснювати, що таке знижка, } \\
\text { дисконт }\end{array}$ & $\begin{array}{l}\text { шахрайство з боку продавців на } \\
\text { дисконтах }\end{array}$ \\
\hline & & $\begin{array}{l}\text { активізація продажів та залучення нових } \\
\text { клієнтів на короткий період }\end{array}$ & $\begin{array}{l}\text { відсутність механізму впливу на } \\
\text { поведінку покупців }\end{array}$ \\
\hline
\end{tabular}




\begin{tabular}{|c|c|c|c|}
\hline & & & Продовження табл. 2 \\
\hline 1 & 2 & 3 & 4 \\
\hline \multirow[t]{6}{*}{3} & \multirow{6}{*}{$\begin{array}{l}\text { Програми винагород } \\
\text { (програми лояльності, у } \\
\text { рамках яких покупці } \\
\text { згодом отримують } \\
\text { фінансові вигоди за } \\
\text { операції проведені в } \\
\text { минулому) }\end{array}$} & $\begin{array}{l}\text { довгострокова дія програми, яку важко } \\
\text { скопіювати конкурентам }\end{array}$ & $\begin{array}{l}\text { неправильність визначення розміру } \\
\text { cashback у фіксованих сумах, коли сума } \\
\text { покупки менше ніж фіксована сума } \\
\text { cashback }\end{array}$ \\
\hline & & $\begin{array}{l}\text { можливість матеріального заохочення } \\
\text { покупця в залежності від його } \\
\text { активності }\end{array}$ & $\begin{array}{l}\text { обслуговування карток з cashback коштує } \\
\text { дорожче, ніж звичайних варіантів карток }\end{array}$ \\
\hline & & $\begin{array}{l}\text { можливість залучення постійного } \\
\text { покупця до просування програми }\end{array}$ & $\begin{array}{l}\text { менше стимулювання повторних покупок } \\
\text { ніж в бонусній програмі }\end{array}$ \\
\hline & & $\begin{array}{l}\text { стовідсоткова гарантія повернення } \\
\text { відсотка від витрат }\end{array}$ & \\
\hline & & $\begin{array}{l}\text { повертаються кошти в якості реальних } \\
\text { грошей, які можна швидко зняти або } \\
\text { оплатити ними нові покупки }\end{array}$ & \\
\hline & & $\begin{array}{l}\text { зазвичай пропонується безвідсоткове } \\
\text { користування кредитом з пільговим } \\
\text { періодом, в який не сплачуються } \\
\text { відсотки по кредиту, але гроші все одно } \\
\text { повертаються. }\end{array}$ & $\begin{array}{l}\text { кошти винагороди покупцями } \\
\text { використовуються повністю і не } \\
\text { залишаються невикористаними у } \\
\text { продавця }\end{array}$ \\
\hline
\end{tabular}

* Узагальнено авторами за [17-20]

Таким чином, кожний вид програми лояльності має свої переваги та недоліки i дозволяє здійснювати заохочення покупців відповідно до обраної торговцем мети, а саме: або стимулювання продажів або залучення нових покупців. При цьому дуже важлива правильність оцінки кожного виду програм лояльності у системі бухгалтерського обліку 3 метою визначення iii ефективності та подальших напрямів розвитку.

Діючий у вітчизняній практиці порядок обліку розрахунків 3 покупцями в умовах застосування дисконтних програм лояльності, коли знижки надаються в момент продажу, призводить до того, що знижки в бухгалтерському обліку взагалі не відображаються - вони фактично припиняють існувати після того, як товар відпущено або продано покупцю.

Другий та третій види програм лояльності бонусні програм та програми відшкодування ще не так давно практично не використовувалися в Україні. Особливість цих видів програм лояльності полягає в тому, що бонуси та відшкодування надають покупцям не в момент продажу товару, а зазвичай після закінчення звітного періоду і відображаються вони в бухгалтерському обліку вони по-різному.

Найбільш розповсюджена в Україні форма відображення в бухгалтерському обліку бонусних програм лояльності це привілеї покупцям як безкоштовне постачання товарів та одночасне списання віртуальних бонусів. Діючий у вітчизняній практиці порядок обліку розрахунків 3 покупцями в умовах застосування бонусних програм лояльності, коли покупцю відвантажується безкоштовно товар не вельми зручний варіант надання привілеїв, оскільки при цьому виникають проблеми з податковим обліком.

У бухгалтерському обліку витрати, пов'язані 3 безкоштовним постачанням товарів постачальника відображаються на рахунку 93 «Витрати на збут» при цьому класифікують як витрати на продаж, керуючись міжнародним стандартом бухгалтерського обліку 2 (МСБО 2).

Найпоширеніші в Україні варіанти відображення в бухгалтерському обліку програм відшкодування це надання привілеїв покупцям як коригування цін або як грошова премія.

Надання привілеїв покупцям як коригування цін відображаються в обліку по-різному, залежно від того, здійснено розрахунки з покупцями чи нi.

До моменту оплати товару продавець здійснює коригування ціни в бухгалтерському обліку шляхом зменшення дебіторської заборгованості на рахунку 36 «Розрахунки 3 покупцями та замовниками», при цьому керуючись положеннями МСБО 1 «Подання фінансової звітності», МСБО 18 «Дохід», МСБО 32 «Фінансові інструменти: подання», МСБО 39 «Фінансові інструменти: визнання й оцінка».

Після продажу товарів продавець відображає зменшення доходу за субрахунком 704 «Відрахування 3 доходу», при цьому в обліку використовують засади міжнародного стандарту бухгалтерського обліку 18 (МСБО 18 «Дохід»).

Надання привілеїв покупцям у вигляді грошової премії відображаються в обліку як сума компенсації яку переказує продавець покупцю за точність закупівельних прогнозів, виконання плану узгоджених закупівель, дотримання 
асортименту товарів, тощо. 3 точки зору обліку такі грошові премії вважаються оплатою маркетингових послуг, а компенсації, що сплачуються покупцю, виступають оплатою таких послуг. Таким чином, продавець такі отримані маркетингові послуги включає до витрат на збут та відображає на рахунку 93 «Витрати на збут» керуючись при цьому, міжнародним стандартом бухгалтерського обліку 2 (МСБО 2).

Інтеграція України в Європейське Співтовариство вимагає впровадження єдиних підходів до складання фінансової звітності. [21]. Відповідно до цього 3 початку 2018 року в Україні стане обов'язковим для використання новий міжнародний стандарт фінансової звітності - МСФЗ 15 «Доходи від контрактів із клієнтами», який було ухвалено ще в листопаді 2011 року.

До моменту набрання чинності новим стандартом облік доходів здійснюється згідно 3 МСБО 18 «Дохід». [21]. Новий Стандарт МСФЗ 15 є більш директивним стандартом, основний принцип якого полягає в тому, що компанія повинна визнати виручку від передачі товарів згідно контракту покупцям у сумі, яка відображає очікувану винагороду в обмін на ці товари.

Отже, відповідно до нового стандарту МСФ3 15 «Доходи від контрактів із клієнтами» (IFRS 15 Revenue from Contracts with Customers) компанія має визнавати дохід мірою виконання зобов'язань. Зокрема в рамках майбутньої концепції обліку обов'язки продавців 3 реалізації дисконтних, бонусних програм лояльності та програм винагород у вигляді знижок на придбання товарів, нарахування бонусів, у майбутньому, надання інших додаткових вигод покупцям не будуть обліковуватись у складі витрат, а сприйматимуться як зобов'язання відповідно до контракту з покупцями [22].

Таким чином, доходи щодо виконання таких контрактів мають визнаватись відповідно до виконання зобов'язань за цим контрактом, а кожна торговельна операція в даному випадку повинна аналізуватись окремо по кожному компоненту у відповідному звітному періоді.

Отже, при нарахуванні покупцям додаткових бонусів за придбанні товари, що $є$ відображенням права на придбання товарів у майбутньому безкоштовно чи зі знижкою, компанії повинні окремо відображати в звітності вартісну оцінку такої обіцянки шляхом відстрочки визнання доходу до моменту виконання відповідного зобов'язання або закінчення терміну використання нарахованих бонусів.
Таким чином, відповідно до майбутнього нового стандарту МСФЗ 15 «Доходи від контрактів із клієнтами» виникає потреба в запровадженні нового об'єкту обліку субрахунку «Доходи майбутніх періодів від програм лояльності» до рахунку 69 «Доходи майбутніх періодів», який дозволить в повній мірі та правдиво відображати торговельні операції з наданням бонусів та кеш-беків після дати первинної реалізації в обліку компаній, що отримують привілеї за бонусними програмами лояльності та програмами винагород.

Разом 3 цим, для торгових підприємств, що здійснюють реалізацію товарів за бонусними програмами лояльності та програмами винагород, на думку авторів, $є$ потреба у запровадженні, нового об'єкту обліку субрахунку «Витрати майбутніх періодів за програми лояльності» до рахунку 39 "Витрати майбутніх періодів"

Також відповідно до майбутнього нового стандарту МСФ3 15 «Доходи від контрактів із клієнтами» виникає потреба в запровадженні нового об'єкту обліку - субрахунку «Втрачені бонуси та знижки» для відповідного списання упущених привілеїв із закінченням терміну їх використання.

Таким чином, вищевикладені пропозиції щодо запровадження нових об'єктів обліку доповнюють один одного, ускладнюючи, в силу появи нових умов i факторів впровадження програм лояльності в торгівлі, в яких розвивається сучасний бізнес.

Висновки i перспективи подальших досліджень. Проведене дослідження дає авторам можливість запропонувати класифікацію програм лояльності, виходячи 3 потреб бухгалтерського обліку на дисконтні, бонусні та програми винагород.

Здійснена порівняльна характеристика програм лояльності в торгівлі дозволила авторам визначити переваги та недоліки кожного виду програм лояльності, розуміння та використання яких в системі управлінського обліку дасть можливість зменшити ризики операційної діяльності та підвищити доходність кампаній від реалізації програм лояльності в торгівлі.

Оскільки бухгалтерський облік не може бути відокремленим від суспільно-економічних змін, він покликаний максимально сприяти впровадженню різних видів програм лояльності і особливо в торгівлі. Отже, подальшим напрямом наукового дослідження $\epsilon$ розробка методики бухгалтерського обліку розрахунків з покупцями в торгівлі в умовах застосування програм лояльності та практичного застосування оцінки доходності від реалізації цих програм. 


\section{ПЕРЕЛІК ВИКОРИСТАНИХ ДЖЕРЕЛ}

1. Валентинова Т. Видача покупцям карток на бонуси (знижки): тонкощі обліку та оподаткування. / Т. В. Валентинова //Все про бухгалтерський облік. - 2012. - № 109-110.- С.70-73.

2. Ларка M.І., Мірошник М.В та ін. Сучасні тенденції та проблеми розвитку програм лояльності на споживчому ринку / М.I. Ларка, М.В Мірошник, В.А. Анохін, І.С Олійник// Вісник НТУ «ХПІ». Серія: Технічний прогрес і ефективність виробництва. - Х.: НТУ «ХПІ». - 2013. - № 66 (1039) - С. 129-137.

3. Юрко І. В., Карась О. М. Розвиток видів програм лояльності торговельних підприємств /I. В. Юрко, О.М.Карась// Науковий вісник Полтавського університету економіки і торгівлі. - 2011.- № 6 (51), ч. 1. С.241246.

4. Іваннікова М. М., Маркетингове управління лояльністю споживачів/ М. М. Іваннікова// Маркетинг i менеджмент інновацій. - 2014. - № 3. - С. 62-72.

5. Козейчук Д. А. Лояльность как ключевой фактор стоимости бренда / Д. А. Козейчук // Современные аспекты экономики. - 2015. - № 8 (75). - С. 255-259.

6. Куликова 3. В. О целесообразности управления лояльностью / 3. В. Куликова // Практический маркетинг. - 2014. - № 5. - C. 6-9.

7. Широченская И. П. Основные понятия и методы измерения лояльности / И. П. Широченская // Маркетинг в России и за рубежом. - 2014. - № 2. - С. 15-17.

8. Бутчер С. Программы лояльности и клубы постоянных клиентов / Стефан Бутчер; [пер. с англ. Е.В. Трибушиной]. - Москва.: Изд. Дом «Вильямс», 2013. - 272с.

9. Гембл П. Маркетинг взаимоотношений с потребителями / П. Гембл, М. Стоун, Н. Вудкок; пер. с англ. М.: Гранд, 2012. $-511 \mathrm{c.}$

10. Ньюэлл Ф. Почему не работают системы управления отношениями с клиентами (CRM) / Ф. Ньюэлл ; пер. с англ. - М.: Добрая книга, 2014. - 368 с.

11. Райхельд Ф. Искренняя лояльность: ключ к завоеванию клиентов на всю жизнь / Ф. Райхельд при участии Р. Марки; пер. с англ. С. Филина. - М.: Манн, Иванов и Фербер, 2013. - 347 с.

12. Соболєва-Терещенко О.А., Жарнікова В.В. Теоретико-методологічні основи формування ефективних систем лояльності / О.А. Соболєва-Терещенко, В.В. Жарнікова // Журнал Менеджер. - 2017.- № 2(75), С. 8291.

13. Кляченко I.О., Зозульов О.В. Програми лояльності споживачів до бренду [Електронне видання] // Актуальні проблеми економіки та управління: Зб. наук. праць. - К.: НТУУ „КПІ”. - Вип. 6. - 2012. - Режим доступу до журналу: http://probl-economy.kpi.ua/node/263

14. Герия И.А. Программы лояльности и оценка их эффективности / И. А. Герия // Научно-практический журнал “Управление и экономика в XXI веке”. - 2015. - № 1. - С. 47-52

15. Серия «Банковское дело»: в 5 т. Том 4. Банковский маркетинг. / Под ред. Ровенского Ю.А., Наточеевой Н.Н.// Учебник "Business \& Economics". - 2016 -271 стр.

16. Loyalty analytics exposed: What every program manager needs to know. PricewaterhouseCoopers LLP. - 2013, p.3 [Електронний ресурс]. - Режим доступу: http://www.pwc.com/us/en/insurance/publications/assets/pwc-loyaltyanalyticsexposed. Pdf

17. Серпенінова Ю. С. Проблемні аспекти облікового відображення бонусних програм лояльності клієнтів / Ю. С. Серпенінова // Вісник Сумського державного університету. Серія Економіка. — 2014. — №1 . — С. 68-73.

18. Наумчик Е.А Возможности и недостатки различных видов программ лояльности - 2013. — [Електронний pecypc]. - Режим доступу: http://www.marketing.spb.ru/lib-comm/dm/loyal_progr_types.htm

19. Ергина М.А Рамки эффективности программ лояльности - 2007. - [Електронний ресурс]. - Режим доступу: http://www.msk-reklama.ru/sale_prom_st_02.html

20. Что такое кэшбэк и как работают сервисы, предлагающие эту услугу. - 2015. - [Електронний ресурс]. Режим доступу: http://cursinfo.com/cashback/

21. Контракти із замовниками: аспекти використання МСФ3 15 «Виручка за контрактами 3 клієнтами» [Електронне видання] // Відкрита Міжнародна інтернет-конференція "МСФЗ: дослідження, наука, практика, імплементація". - 2014. - Режим доступу: http://konf.amsfo.com.ua/kontrakti-iz-zamovnikami-aspektivikoristannya-msfz-15-viruchka-za-kontraktami-z-kliyentami/

22. Амалян А.В. Розкриття у фінансовій звітності інформації в рамках клієнтських програм лояльності у світлі нової глобальної концепції визнання доходу (МСФЗ 15) / А.В. Амалян // Науковий вісник Херсонського державного університету . - 2015. - № 14 (2). - С. 134-137.

\section{REFERENCES}

1. Valentynova, T. (2012). Vydacha pokuptsiam kartok na bonusy (znyzhky): tonkoshchi obliku ta opodatkuvannia [Issuance of buyers of cards for bonuses (discounts): subtleties of accounting and taxation] Vse pro bukhhalterskyi oblik - All about accounting, 109-110, 70-73 - 2012. [in Ukrainian].

2. Larka, M.I. \& Miroshnyk M.V. et al. (2013). Suchasni tendentsii ta problemy rozvytku prohram loialnosti na spozhyvchomu rynku [Modern trends and problems of developing loyalty programs in the consumer market]. Visnyk 
NTU «KhPI». Seriia: Tekhnichnyi prohres i efektyvnist vyrobnytstva - Bulletin of the NTU "KhPI". Ser.: Technical progress and production efficiency. - Kharkiv. NTU "KhPI", 66 (1039), 129-137 [in Ukrainian].

3. Yurko, I. V. \& Karas, O. M. (2011). Rozvytok vydiv prohram loialnosti torhovelnykh pidpryiemstv [Development of types of programs of loyalty of trade enterprises]. Naukovyi visnyk Poltavskoho universytetu ekonomiky i torhivli - Scientific Herald of the Poltava University of Economics and Trade, 6 (51), 241-246 [in Ukrainian].

4. Ivannikova, M. M. (2014). Marketynhove upravlinnia loialnistiu spozhyvachiv [Marketing management of consumer loyalty]. Marketynh i menedzhment innovatsii - Marketing and management of innovations, 3, 62-72. [in Ukrainian].

5. Kozeichuk, D. A. (2015). Loialnost kak kliuchevoi faktor stoimosti brenda [Loyalty as a key factor in brand value ]. Sovremennye aspekty ekonomiki - Modern aspects of economics , 8 (75), 255-259 - 2015. [in Russian].

6. Kulikova, Z. V. (2014). O tcelesoobraznosti upravleniia loialnostiu [About the expediency of loyalty management]. Prakticheskii marketing - Practical marketing, 5, 6-9 - 2014. [in Russian].

7. Shirochenskaia, I. P. (2014). Osnovnye poniatiia i metody izmereniia loialnosti [Basic concepts and methods for measuring loyalty]. Marketing v Rossii i za rubezhom - Marketing in Russia and abroad, 2, 15-17- 2014. [in Russian].

8. Butcher, S. (2013). Programmy loialnosti i kluby postoiannykh klientov [Loyalty programs and regular customers clubs] (E.V. Tribushina, Trans). Moscow: Izd. Dom «Viliams» [in Russian].

9. Gembl, P. (2012). Marketing vzaimootnoshenii s potrebiteliami [Marketing of relationships with consumers ] (M. Stoun, N. Vudkok, Trans.). Moscow: Grand [in Russian].

10. Newell, F. (2014). Pochemu ne rabotaiut sistemy upravleniia otnosheniiami s klientami (CRM) [Why the system does not work the customer relationship management (CRM) systems ] (F. Niuell, Trans.). Moscow: Dobraia kniga [in Russian].

11. Reicheld, F. (2013). Iskrenniaia loialnost: kliuch k zavoevaniiu klientov na vsiu zhizn [Sincere loyalty: the key to winning customers for life ] (S. Filin, Trans.). Moscow: Mann, Ivanov and Ferber [in Russian].

12. Sobolieva-Tereshchenko, O.A. \& Zharnikova, V.V. (2017). Teoretyko-metodolohichni osnovy formuvannia efektyvnykh system loialnosti [Theoretical and methodological foundations of the formation of effective systems of loyalty]. Zhurnal Menedzher - Journal of the Manager. 2(75), 82-91 [in Ukrainian].

13. Kliachenko, I.O. \& Zozulov, O.V. (2012). Prohramy loialnosti spozhyvachiv do brendu [Consumer Loyalty to the Brand]. Aktualni problemy ekonomiky ta upravlinnia - Current issues in economics and management, Retrieved from: http://probl-economy.kpi.ua/node/263 [in Ukrainian].

14. . Geriia, I.A. (2015) Programmy loialnosti i otcenka ikh effektivnosti [Loyalty programs and evaluation of their effectiveness]. Nauchno-prakticheskii zhurnal "Upravlenie i ekonomika v XXI veke" - Scientific and Practical Journal "Management and economics in the 21st Century", 1, 47-52 - 2015. [in Russian].

15. Rovenskii, Iu.A. \& Natocheeva N.N. (Ed.). (2016). Seriya «Bankovskoye delo»: Bankovskiy marketing. [Series "Banking": Banking marketing.]. (Vol.4) Moscow: "Business \& Economics" [in Ukrainian].

16. Loyalty analytics exposed: What every program manager needs to know. PricewaterhouseCoopers LLP. Retrieved from: http://www.pwc.com/us/en/insurance/

publications/assets/pwc-loyalty-analyticsexposed.pdf [in English].

17. Serpeninova, Iu. S (2014). Problemni aspekty oblikovoho vidobrazhennia bonusnykh prohram loialnosti kliientiv [Problematic aspects of accounting reflection of customer loyalty bonus programs]. Visnyk Sumskoho derzhavnoho universytetu. Seriia Ekonomika. - Bulletin of Sumy State University. Series Economics, 1, 68-73- 2014. [in Ukrainian].

18. Naumchik, E.A Vozmozhnosti i nedostatki razlichnykh vidov programm loialnosti [Opportunities and disadvantages of various types of loyalty programs]. Retrieved from: http://www.marketing.spb.ru/libcomm/dm/loyal_progr_types.htm [in Russian].

19. Ergina M.A Ramki effektivnosti programm loialnosti [Framework for the effectiveness of loyalty programs]. Retrieved from: http://www.msk-reklama.ru/sale_prom_st_02.html [in Russian].

20. Chto takoe keshbek i kak rabotaiut servisy, predlagaiushchie etu uslugu [What is the cashback and how the services that offer this service work]. Retrieved from: http://cursinfo.com/cashback/ [in Russian].

21. Kontrakty iz zamovnykamy: aspekty vykorystannia MSFZ 15 «Vyruchka za kontraktamy z kliientamy» [Customer contracts: Aspects of using IFRS 15 "Revenue from customer contracts"] Retrieved from: http://konf.amsfo.com.ua/kontrakti-iz-zamovnikami-aspekti-vikoristannya-msfz-15-viruchka-za-kontraktami-zkliyentami/ [In Ukrainian].

22. Amalian, A.V. (2015). Rozkryttia u finansovii zvitnosti informatsii v ramkakh kliientskykh prohram loialnosti u svitli novoi hlobalnoi kontseptsii vyznannia dokhodu (MSFZ 15) [Disclosure of financial reporting of information in the field of customer loyalty programs in the towards of the new global income recognition concept (IFRS 15)]. Naukovyi visnyk Khersonskoho derzhavnoho universytetu - Scientific Herald of the Kherson State University, 14 (2), 134-137- 2015 [in Ukrainian]. 